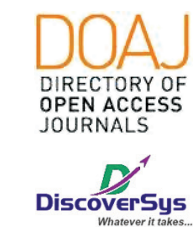

Published by DiscoverSys

\title{
Profil penderita Chronic Kidney Disease (CKD) stadium 5 yang menjalani hemodialisis reguler di Rumah Sakit Umum Daerah (RSUD) Klungkung, Bali, Indonesia
}

\author{
Dewa Ayu Sri Agung Suandewi, ${ }^{1{ }^{*}}$ I Gede Restu Mahendra Sugiarta, ${ }^{1}$ \\ Nyoman Tri Astawa, ${ }^{2,3}$ I Putu Ekariawan ${ }^{3}$
}

\section{ABSTRACT}

Background: Chronic Kidney Disease (CKD) is one of the chronic diseases which becomes a major public health problem in Indonesia. The proportion of CKD patient that underwent hemodialysis in Indonesia and Bali in 2018 was 19,3\% and 38,7\%. This study aims to determine the sociodemographic and clinical profile of patients with CKD stage 5 who underwent regular hemodialysis at Klungkung District General Hospital in 2019.

Method: A retrospective cross-sectional study was conducted among 77 samples in the hemodialysis unit of Klungkung District General Hospital by using secondary data obtained from medical records by the total sampling method. The inclusion criteria were patients with CKD stage 5 , who underwent regular hemodialysis. The variables evaluated in this study were age, level of education, work status, marriage status, HD period, etiology, vascular access, $\mathrm{HBsAg}$, and level of hemoglobin. Data were analyzed by SPSS version 21 for Windows.
Result: The proportion of patient with CKD stage 5 who underwent hemodialysis was 51 to 60 years (33.8\%), male gender patients (63.6\%), senior high school education (42.9\%), working (59.7\%), married (93.5\%), the duration of year that underwent hemodialysis between 1 to 5 years $(85.7 \%)$, the most common etiology is chronic pyelonephritis (32.5\%), with AV Shunt as vascular access (63.6\%), HBsAg test was negative (96.1\%), and $\mathrm{Hb}$ levels > $10 \mathrm{~g} / \mathrm{dL}(54.5 \%)$.

Conclusion: Most patients with CKD stage 5 who underwent hemodialysis at Klungkung District General Hospital are male patients, middle age, secondary education level, dominant is working and married, with the first year undergoing hemodialysis 1-5 years. The most common cause of CKD is chronic pyelonephritis in males and hypertension in females.

Keywords: Profile, CKD stage 5, Hemodialysis, Proportion, Klungkung

Cite This Article: Suandewi, D.A.S.A., Sugiarta, I.G.R.M., Astawa, N.T., Ekariawan, I.P. 2020. Profil penderita Chronic Kidney Disease (CKD) stadium 5 yang menjalani hemodialisis reguler di Rumah Sakit Umum Daerah (RSUD) Klungkung, Bali, Indonesia. Intisari Sains Medis 11(2): 613-619. D0I: 10.15562/ism.v11i2.624

'Dokter Umum, Fakultas Kedokteran Universitas Udayana, Bali, Indonesia

${ }^{2}$ SMF IImu Penyakit Dalam Rumah Sakit Umum Daerah (RSUD) Klungkung, Bali, Indonesia ${ }^{3}$ Unit Hemodialisis Rumah Sakit Umum Daerah (RSUD) Klungkung, Bali, Indonesia

\section{"Korespondensi:}

Dewa Ayu Sri Agung Suandewi, Dokter Umum, Fakultas Kedokteran Universitas Udayana, Bali, Indonesia, Fakultas Kedokteran Universitas Udayana;

suandewisri@gmail.com

Diterima: 17-09-2019

Disetujui: $30-05-2020$

Diterbitkan: 01-08-2020

\section{ABSTRAK}

Latar Belakang: Chronic Kidney Disease (CKD) merupakan salah satu penyakit kronis terbanyak yang menjadi masalah kesehatan masyarakat di Indonesia. Angka proporsi penderita CKD yang menjalani hemodialisis di Indonesia dan di Bali tahun 2018 adalah 19,3\% dan 38,7\%. Penelitian ini bertujuan untuk mengetahui profil sosiodemografi dan klinis penderita CKD stadium 5 yang menjalani hemodialisis reguler di RSUD Klungkung tahun 2019.

Metode: Penelitian retrospektif potong lintang dilakukan terhadap 77 sampel di unit hemodialisis Rumah Sakit Umum Daerah Klungkung dengan menggunakan data sekunder yang diperoleh dari catatan medis dengan metode total sampling. Kriteria inklusi adalah pasien dengan CKD stadium 5 yang menjalani hemodialisis reguler. Variabel yang dievaluasi dalam penelitian ini adalah usia, tingkat pendidikan, status pekerjaan, status pernikahan, masa HD, etiologi, akses vaskular, $\mathrm{HBs} A \mathrm{~g}$, dan kadar hemoglobin. Data dianalisis oleh SPSS versi 21 untuk Windows.
Hasil: Proporsi penderita CKD stadium 5 yang menjalani hemodialisis umumnya berada pada rentang umur $51 \mathrm{~s} / \mathrm{d} 60$ tahun (33,8\%), dengan jenis kelamin penderita terbanyak laki-laki $(63,6 \%)$, pendidikan SMA $(42,9 \%)$, bekerja $(59,7 \%)$, menikah $(93,5 \%)$, durasi tahun menjalani hemodialisis antara $1 \mathrm{~s} / \mathrm{d} 5$ tahun $(85,7 \%)$, etiologi yang umum ditemui adalah pielonefritis kronis (32,5\%), dengan akses vaskular AV Shunt $(63,6 \%)$, tes HbsAg umumnya negatif $(96,1 \%)$, dan kadar $\mathrm{Hb}$ $>10 \mathrm{gram} / \mathrm{dL}(54,5 \%)$.

Simpulan: Sebagian besar penderita CKD stadium 5 yang menjalani hemodialisis di RSUD Klungkung adalah penderita laki - laki, umur pertengahan, tingkat pendidikan menengah, dominan sudah bekerja dan sudah menikah, dengan tahun pertama menjalani hemodialisis 1-5 tahun. Penyebab paling umum dari CKD adalah pielonefritis kronis pada pria dan hipertensi pada wanita. 
Kata Kunci: Profil, CKD Stadium 5, Hemodialisis, Proporsi, Klungkung.

Cite Pasal Ini: Suandewi, D.A.S.A., Sugiarta, I.G.R.M., Astawa, N.T., Ekariawan, I.P. 2020. Profil penderita Chronic Kidney Disease (CKD) stadium 5 yang menjalani hemodialisis reguler di Rumah Sakit Umum Daerah (RSUD) Klungkung, Bali, Indonesia. Intisari Sains Medis 11(2): 613-619. DOl: 10.15562/ism.v11i2.624

\section{PENDAHULUAN}

Chronic Kidney Disease (CKD) merupakan salah satu penyakit kronis terbanyak yang menjadi masalah kesehatan masyarakat di Indonesia dan di dunia. ${ }^{1,2}$ Peningkatan insiden dan prevalensi, biaya perawatan rumah sakit, serta hasil keluaran penyakit yang buruk meningkatkan angka mortalitas dan morbiditas penderita CKD. ${ }^{1,2}$ CKD merupakan penyebab nomor 12 terbanyak untuk angka mortalitas dan nomor 17 untuk angka morbiditas. ${ }^{3,4}$ Prevalensi penderita CKD stadium 5 di dunia pada tahun 2014 cukup tinggi, yaitu $0,13 \%$ (sekitar 10 juta jiwa di dunia). ${ }^{5}$ Berdasarkan hasil meta-analisis dari 100 penelitian, rerata prevalensi CKD secara global adalah 13,4\% dengan prevalensi CKD stadium 5 sebesar $0,1 \%{ }^{6}$ Sebanyak 500 juta orang diperkirakan menderita CKD dengan mayoritas penderita (80\%) berada di negara berpenghasilan rendah hingga sedang. ${ }^{7}$ Laporan hasil Riset Kesehatan Dasar (Riskesdas) Departemen Kesehatan Republik Indonesia (Depkes RI) tahun 2018, menunjukkan prevalensi CKD (per mil) $\geq 15$ tahun berdasarkan diagnosis dokter tahun 2013-2018 di Indonesia adalah 3,8\%. ${ }^{8}$

Hemodialisis masih menjadi modalitas terapi pengganti ginjal di dunia, terutama di negara Singapura, Malaysia, dan Indonesia. ${ }^{9,10}$ Proporsi penderita yang pernah atau sedang menjalani hemodialisis pada penduduk berumur $\geq 15$ tahun yang terdiagnosis CKD di Indonesia tahun 2018 adalah 19,3\%, dengan provinsi Bali sebagai urutan terbanyak kedua di Indonesia setelah DKI Jakarta dengan $38,7 \%{ }^{8}$

Penelitian sebelumnya di Indonesia menunjukkan bahwa sebanyak 92,1\% dari 382 unit hemodialisis yang ada di Indonesia adalah di klinik (7,9\%) dan di rumah sakit $(92,1 \%) .{ }^{11}$ Rumah Sakit Umum Daerah (RSUD) Klungkung merupakan salah satu rumah sakit utama tipe B milik pemerintah kabupaten Klungkung yang terletak di kota Klungkung dengan memiliki 1 unit hemodialisis aktif dan jadwal rutin hemodialisisnya setiap 2 kali dalam seminggu. Survei pendahuluan berdasarkan data register di unit hemodialisis RSUD Klungkung, menunjukkan bahwa jumlah penderita CKD stadium 5 yang menjalani hemodialisis reguler di RSUD Klungkung tahun 2019 adalah 77 orang.

Penelitian ini dilakukan untuk mengetahui profil penderita CKD stadium 5 yang menjalani hemodialisis reguler di RSUD Klungkung berdasarkan sosiodemografi (umur, jenis kelamin, pendidikan, status pekerjaan, dan status pernikahan), dan klinis (lama tahun menjalani hemodialisis, etiologi, akses vaskular yang digunakan, $\mathrm{HbsAg}$ penderita, dan kadar Hemoglobin ( $\mathrm{Hb}$ ) penderita).

\section{METODE}

Penelitian ini merupakan penelitian deskriptif dengan metode cross sectional retrospektif yang bertujuan untuk mengetahui profil proporsi penderita CKD stadium 5 yang menjalani hemodialisis reguler di RSUD Klungkung. Setiap penderita CKD stadium 5 yang menjalani hemodialisis reguler di RSUD Klungkung mendapat 2 kali hemodialisis dalam 1 minggu dengan rata-rata waktu selama 4,5 jam dalam 1 kali dilakukan hemodialisis per harinya sesuai jadwal yang telah didapatkan oleh pihak hemodialisis RSUD Klungkung (SeninKamis, Selasa-Jumat, dan Rabu-Sabtu) dan dibagi 2 sesi dalam 1 harinya, yaitu sesi pagi dan sesi siang.

Penelitian ini dilaksanakan di unit hemodialisis RSUD Klungkung dengan pertimbangan tersedianya data rekam medis yang lengkap mengenai penderita CKD stadium 5 yang menjalani hemodialisis reguler. Data yang digunakan adalah data sekunder yang diperoleh dari catatan rekam medis penderita CKD stadium 5 yang menjalani hemodialisis reguler di RSUD Klungkung dari bulan Januari 2018 sampai dengan bulan Juli 2019. Jenis data yang digunakan adalah data kuantitatif. Populasi dan sampel pada penelitian ini adalah semua penderita CKD stadium 5 yang menjalani hemodialisis reguler di RSUD Klungkung. Jumlah sampel pada penelitian ini berjumlah 77 orang dengan metode total sampling yang didapat dari hasil survei pendahuluan di RSUD Klungkung pada bulan Juli tahun 2019. Penderita CKD stadium 5 yang meninggal atau penderita CKD stadium 5 yang menjalani hemodialisis tetapi tidak mendapat jadwal atau tidak rutin menjalani hemodialisis di RSUD Klungkung ditetapkan sebagai kriteria eksklusi dalam penelitian ini.

Keseluruhan data dikumpulkan dan dicatat di program Microsoft Office Excel 2010, kemudian diolah dan dianalisis secara deskriptif menggunakan program SPSS Statistics 21 untuk ditampilkan dalam bentuk tabel. 


\section{HASIL}

Tabel 1 menunjukkan proporsi penderita CKD stadium 5 yang menjalani hemodialisis reguler di RSUD Klungkung. Hasil penelitian menunjukkan bahwa proporsi demografi pasien paling tinggi ditemukan pada kelompok usia 51-60 tahun $(33,8 \%)$, diikuti dengan jenis kelamin laki-laki $(63,6 \%)$, tingkat pendidikan SMA $(42,9 \%)$, dan status bekerja sebesar $(59,7 \%)$. Terdapat perbedaan proporsi bahwa laki-laki lebih banyak bekerja sebesar $73,5 \%$ dan perempuan lebih banyak tidak bekerja sebesar 64,3\% (Tabel 1).

Disamping itu sebagian besar pasien telah menikah (93,5\%), 1 s/d 5 tahun menjalani HD $(85,7 \%)$, etiologi pielonefritis kronis $(41,5 \%)$, penggunaan Arterial-Venosus (AV) shunt (63,6\%), HBsAg negatif $(96,1 \%)$, dan pada kelompok kadar hemoglobin $(\mathrm{Hb})>10$ gram/dL $(54,5 \%)$ (Tabel 1). Terdapat perbedaan bahwa laki-laki lebih banyak dengan kadar $\mathrm{Hb}>10$ gram/dL sebesar 67,3\% dan perempuan lebih banyak dengan kadar $\mathrm{Hb} 7$ 10 gram/dL sebesar 64,3\% (Tabel 1).

\section{PEMBAHASAN}

Proporsi penderita CKD stadium 5 di RSUD Klungkung berdasarkan jenis kelamin lebih tinggi pada laki-laki dibandingkan perempuan. Hasil ini sesuai dengan laporan Riskesdas tahun 2013 yang menunjukkan bahwa angka prevalensi CKD pada

Tabel 1 Proporsi Penderita CKD Stadium 5 yang Menjalani Hemodialisis Reguler di RSUD Klungkung

\begin{tabular}{|c|c|c|c|c|}
\hline Variabel & Kategori & Laki-laki ( $=49)$ & Perempuan $(\mathbf{N}=\mathbf{2 8})$ & Persentase (\%) \\
\hline \multirow[t]{6}{*}{ Umur Penderita, n (\%) } & $21 \mathrm{~s} / \mathrm{d} 30$ tahun & $4(8,2)$ & $0(0)$ & $4(5,2)$ \\
\hline & $31 \mathrm{~s} / \mathrm{d} 40$ tahun & $4(8,2)$ & $3(10,7)$ & $7(9,1)$ \\
\hline & $41 \mathrm{~s} / \mathrm{d} 50$ tahun & $10(20,4)$ & $9(32,1)$ & $19(24,7)$ \\
\hline & $51 \mathrm{~s} / \mathrm{d} 60$ tahun & $14(28,5)$ & $12(42,9)$ & $26(33,8)$ \\
\hline & $61 \mathrm{~s} / \mathrm{d} 70$ tahun & $12(24,5)$ & $4(14,3)$ & $16(20,8)$ \\
\hline & $71 \mathrm{~s} / \mathrm{d} 80$ tahun & $5(10,2)$ & $0(0)$ & $5(6,5)$ \\
\hline \multirow[t]{5}{*}{ Pendidikan, n (\%) } & Tidak Sekolah & $9(18,4)$ & $9(32,2)$ & $18(23,4)$ \\
\hline & $\mathrm{SD}$ & $10(20,4)$ & $5(17,9)$ & $15(19,5)$ \\
\hline & SMP & $5(10,2)$ & $2(7,1)$ & $7(9,1)$ \\
\hline & SMA & $23(46,9)$ & $10(35,7)$ & $33(42,9)$ \\
\hline & Sarjana/Diploma & $2(4,1)$ & $2(7,1)$ & $4(5,2)$ \\
\hline \multirow[t]{2}{*}{ Status Pekerjaan, n (\%) } & Bekerja & $36(73,5)$ & $10(35,7)$ & $46(59,7)$ \\
\hline & Tidak Bekerja & $13(26,5)$ & $18(64,3)$ & $31(40,3)$ \\
\hline \multirow[t]{2}{*}{ Status Pernikahan } & Menikah & $45(91,8)$ & $27(96,4)$ & $72(93,5)$ \\
\hline & Tidak Menikah & $4(8,2)$ & $1(3,6)$ & $5(6,5)$ \\
\hline \multirow[t]{3}{*}{ Lama Tahun Menjalani HD, n (\%) } & $<1$ Tahun & $3(6,1)$ & $2(7,1)$ & $5(6,5)$ \\
\hline & $1 \mathrm{~s} / \mathrm{d} 5$ Tahun & $40(81,6)$ & $26(92,9)$ & $66(85,7)$ \\
\hline & $>5$ Tahun & $6(12,3)$ & $0(0)$ & $6(7,8)$ \\
\hline \multirow[t]{5}{*}{ Etiologi, n (\%) } & Hipertensi & $10(20,4)$ & $13(46,4)$ & $23(29,9)$ \\
\hline & Pielonefritis Kronis & $25(51)$ & $7(25)$ & $32(41,5)$ \\
\hline & Glomerulonefritis Kronis & $4(8,2)$ & $1(3,6)$ & $5(6,5)$ \\
\hline & Diabetes Mellitus & $8(16,3)$ & $6(21,4)$ & $14(18,2)$ \\
\hline & Polycystic Kidney Disease & $2(4,1)$ & $1(3,6)$ & $3(3,9)$ \\
\hline \multirow[t]{3}{*}{ Akses Vaskular, n (\%) } & AV Shunt & $32(65,3)$ & $17(60,7)$ & $49(63,6)$ \\
\hline & Femoral & $15(30,6)$ & $10(35,7)$ & $25(32,5)$ \\
\hline & Double Lumen & $2(4,1)$ & $1(3,6)$ & $3(3,9)$ \\
\hline \multirow[t]{2}{*}{ HBsAg, n (\%) } & Positif & $2(4,1)$ & $1(3,6)$ & $3(3,9)$ \\
\hline & Negatif & $47(95,9)$ & $27(96,4)$ & $74(96,1)$ \\
\hline \multirow[t]{3}{*}{ Kadar Hb, n (\%) } & $<7$ gram $/ \mathrm{dL}$ & $0(0)$ & $1(3,6)$ & $1(1,3)$ \\
\hline & $7-10$ gram $/ \mathrm{dL}$ & $16(32,7)$ & $18(64,3)$ & $34(44,2)$ \\
\hline & $>10 \mathrm{gram} / \mathrm{dL}$ & $33(67,3)$ & $9(32,1)$ & $42(54,5)$ \\
\hline
\end{tabular}


laki-laki di Indonesia sebesar 0,3\%, lebih tinggi dari perempuan dengan angka sebesar $0,2 \%{ }^{2}$ Hasil penelitian sebelumnya oleh Silbiger $S$ dan Neugarten J juga menunjukkan prevalensi yang lebih tinggi pada jenis kelamin laki-laki dibandingkan perempuan. ${ }^{12}$

Penelitian oleh Jha VK dan Shashibushan di India, menunjukkan dari 130 penderita CKD stadium 5 yang menjalani hemodialisis, sebanyak $76,2 \%$ penderita adalah laki-laki dengan rasio lakilaki dibanding perempuan 3,19: 1. ${ }^{3}$ Penelitian oleh Chaudhari ST et al., di India, juga menunjukkan dari 50 penderita CKD stadium 5 di India, penderita laki-laki lebih banyak dibandingkan perempuan dengan rasio 1,77: $1 .{ }^{4}$ Penelitian oleh Nomani AZ et al di Pakistan, juga menunjukkan dari 204 kelompok penderita CKD yang menjalani hemodialisis, sebanyak 106 orang penderita diantaranya adalah laki-laki $(51,96 \%)$ sedangkan 98 orang penderita lainnya adalah perempuan $(48,04 \%){ }^{13}$

Penelitian yang sudah dilakukan di beberapa negara menunjukkan lebih banyak penderita laki-laki dengan CKD stadium 5 yang melakukan hemodialisis. Hal ini dikaitkan dengan angkakomorbiditas dengan penyakit sistemik lainnya, serta lakilaki yang lebih banyak memiliki faktor risiko yang didapat seperti merokok, konsumsi alkohol, atau faktor yang diturunkan. ${ }^{14}$ Penurunan fungsi ginjal seiring bertambahnya umur lebih banyak ditemukan pada laki-laki dibandingkan perempuan. Laki-laki juga mengalami gagal ginjal lebih awal dibandingkan dengan perempuan sehingga memiliki tendensi untuk mencari perawatan medis pada CKD stadium 5 yang sudah menunjukkan berbagai gejala klinis. ${ }^{1,14}$

Proporsi penderita CKD stadium 5 di RSUD Klungkung berdasarkan umur lebih tinggi pada umur $51 \mathrm{~s} / \mathrm{d} 60$ tahun. Hasil ini sesuai dengan laporan Riskesdas (2013) yang menunjukkan prevalensi CKD berdasarkan diagnosis dokter meningkat seiring dengan bertambahnya umur. Dimulai dari umur 35-44 tahun sebesar 0,3\%, diikuti rentang umur 45-54 tahun sebesar 0,4\%, rentang umur 55-74 tahun sebesar 0,5\%, dan paling tinggi pada kelompok umur $\geq 75$ tahun sebesar $0,6 \%{ }^{2}$

Penelitian oleh Tjang (2018), juga menunjukkan penderita CKD umumnya berusia $>50$ tahun (44,53\%). ${ }^{1}$ Penelitian oleh Jha VK dan Shashibhushan di India, juga menunjukkan hasil serupa dengan umur penderita CKD stadium 5 yang terbanyak berada di usia 50-59 tahun $(26,2 \%)$ dan umur 60-69 tahun $(39,2 \%){ }^{3}$ Penelitian oleh Chaudhari (2017), juga mendapatkan hasil umur penderita CKD stadium 5 terbanyak pada umur 50-61 tahun (26\%). ${ }^{4}$
Proporsi yang tinggi pada kelompok usia ini disebabkan karena penurunan fungsi ginjal fisiologis mulai terjadi pada usia diatas 40 tahun. Pada rentangan usia 40-60 tahun, pasien CKD stadium 5 masih digolongkan memiliki usia yang produktif sehingga keinginan untuk menjalani pengobatan masih tinggi. Temuan pasien CKD stadium 5 dengan umur $\geq 70$ tahun yang masih menjalani hemodialisis di wilayah Klungkung, kemungkinan disebabkan oleh karena angka harapan hidup masyarakat kabupaten Klungkung yang meningkat setiap tahunnya. ${ }^{15}$

Proporsi penderita CKD stadium 5 di RSUD Klungkung berdasarkan tingkat pendidikan paling tinggi ditemukan pada pendidikan SMA. Hasil ini tidak sesuai dengan laporan Riskesdas (2013) yang menunjukkan prevalensi CKD terbanyak berdasarkan tingkat pendidikan secara berturutturut, adalah tidak sekolah $(0,4 \%), \mathrm{SD}(0,3 \%)$, SMP (0,2\%), SMA (0,1\%), dan D3/PT (0,2\%). ${ }^{2}$ Penelitian oleh Nomani AZ di Pakistan, juga menunjukkan hasil serupa yaitu tidak sekolah $(37,14 \%)$, SD $(24,12 \%)$, SMP $(18,9 \%)$, SMA $(16,50 \%)$, dan Sarjana $(4,12 \%) .^{13}$

Tingkat pendidikan di Bali menurut Profil Kesehatan Provinsi Bali (2017) menunjukkan tingkat pendidikan masyarakat Bali pada umumnya adalah SMA/sederajat (31,70\%), diikuti dengan SD (21,48\%), SMP (17,75\%), Tidak Sekolah (17,70\%), dan Diploma/Sarjana (11,38\%). Hal ini dapat menjelaskan tingkat pendidikan penderita CKD stadium 5 yang tercatat mengikuti hemodialisis di RSUD Klungkung lebih banyak memiliki tingkat pendidikan SMA. ${ }^{15}$

Sebagian besar penderita CKD stadium 5 di RSUD Klungkung adalah bekerja. Hasil ini sesuai dengan laporan Riskesdas (2013) yang menunjukkan penderita CKD yang bekerja sebesar 0,3\%, lebih tinggi dibandingkan yang tidak bekerja sebesar $0,2 \%{ }^{2}$ Penderita yang masih bekerja umumnya berada pada usia produktif, dimana memiliki kondisi fisik yang masih cukup baik. Penderita yang tidak mampu untuk bekerja umumnya memiliki kondisi fisik yang buruk serta komplikasi penyakit yang meningkatkan waktu rawat inap di rumah sakit. ${ }^{12}$

Sebagian besar responden yang dilibatkan pada penelitian ini telah menikah. Hasil yang serupa juga ditemukan pada penelitian Olim MF dari 3.114 penderita di Portugal menunjukkan penderita CKD stadium 5 yang menjalani hemodialisis lebih banyak berstatus menikah (58.7\%). ${ }^{16}$ Penelitian oleh Bawazier LA di Rumah Sakit Cipto Mangunkusumo Jakarta, menyebutkan dari 145 orang penderita CKD stadium 5 yang menjalani hemodialisis juga menunjukkan penderita lebih banyak berstatus menikah (92.4\%) dibandingkan tidak menikah 
(7,6\%). ${ }^{17}$ Penderita CKD umumnya sudah menikah karena usia rerata penderita CKD stadium 5 adalah $\geq 40$ tahun. Di samping itu, adanya dukungan dari pasangan juga membuat penderita menjadi lebih termotivasi untuk mendapatkan perawatan hemodialisis di RSUD Klungkung secara rutin. ${ }^{13}$

Sebagian besar penderita CKD stadium 5 di RSUD Klungkung telah menjalani hemodialisis selama 1-5 tahun. Penelitian oleh Junior (2014) di Brazil menunjukkan hasil serupa, yaitu sebanyak 100 penderita CKD stadium 5 lebih banyak menjalani hemodialisis selama 1-5 tahun (41\%), sedangkan 64 penderita sisanya kurang dari 1 tahun (26\%). ${ }^{14}$ Penelitian oleh Bawazier (2018) di Rumah Sakit Cipto Mangunkusumo Jakarta, juga menunjukkan penderita CKD stadium 5 umumnya telah menjalani terapi hemodialisis selama 1-4 tahun (49\%). ${ }^{17}$ Hasil ini disebabkan oleh karena penderita dengan CKD stadium 5 yang telah menjalani hemodialisis $>5$ tahun kemungkinan lebih banyak yang meninggal sehingga sudah tidak mampu untuk menjalani hemodialisis akibat berbagai kemungkinan komplikasi CKD stadium 5 yang dialaminya. Penderita yang menjalani hemodialisis $<1$ tahun umumnya adalah penderita yang baru menjalani hemodialisis di RSUD Klungkung oleh karena keterbatasan jumlah unit hemodialisis di beberapa tempat dan perlunya dilakukan hemodialisis segera (cito) pada beberapa pasien yang baru terdiagnosis CKD stadium 5 hingga sudah mendapatkan jadwal rutin hemodialisis di RSUD Klungkung.

Proporsi penderita CKD stadium 5 di RSUD Klungkung berdasarkan etiologi secara keseluruhan lebih tinggi pada pielonefritis kronis. Hasil ini tidak sesuai dengan penelitian oleh Bawazier (2018), yang menyatakan bahwa proporsi penderita CKD stadium 5 yang menjalani hemodialisis di RSUP Cipto Mangunkusumo Jakarta berdasarkan etiologi lebih tinggi dengan hipertensi sebesar 40,7\%. ${ }^{17}$ Penelitian lain oleh Chaudhari (2017), menyatakan bahwa proporsi penderita CKD stadium 5 yang menjalani hemodialisis di sebuah rumah sakit negara India berdasarkan etiologi lebih tinggi dengan Diabetic Nephropathy sebesar 32\%. ${ }^{4}$

CKD terjadi setelah terjadinya kerusakan struktur dan fungsi ginjal akibat dari berbagai macam etiologi yang tidak tertangani dengan baik. Pada penelitian ini, laki-laki dengan etiologi berupa pielonefritis kronis menempati urutan tertinggi. Penyebab dasar pielonefritis kronis paling sering oleh karena kelainan struktural ginjal atau adanya obstruksi yang didapat seperti batu saluran kencing (BSK) dan benign prostate hypertrophy (BPH). ${ }^{18}$ Dalam hal ini, kemungkinan adanya obstruksi yang didapat atau riwayat pielonefritis akut yang berulang pada laki-laki menjadi salah satu penyebab etiologi dengan pielonefritis kronis yang paling banyak ditemukan di RSUD Klungkung. Sedangkan Pada perempuan dengan etiologi berupa hipertensi menempati urutan tertinggi. Hipertensi merupakan etiologi lain yang terbanyak pada kasus CKD. Menurut penelitian Alam $M$ et al., hipertensi menempati urutan tertinggi etiologi CKD pada perempuan dengan CKD stadium 5 yang menjalani hemodialisis di sebuah rumah sakit negara Bangladesh sebesar $26 \%{ }^{19}$ Di samping pielonefritis kronis maupun hipertensi, DM juga merupakan etiologi terbanyak yang ditemukan pada penderita CKD. ${ }^{19}$ Menurut US Renal Data System oleh National Center for Chronic Disease Prevention and Promotion tahun 2014, etiologi tersering CKD stadium 5 di Amerika Serikat, yaitu DM (44\% kasus tahun 2014 dan 37,5\% kasus tahun 2015) diikuti dengan hipertensi (29\% kasus tahun 2014 dan $25,1 \%$ kasus tahun 2015). ${ }^{20}$ Dengan demikian, etiologi tertinggi pada penderita CKD stadium 5 yang menjalani hemodialisis berbeda di setiap masing-masing wilayah.

Proporsi penderita CKD stadium 5 di RSUD Klungkung paling tinggi menggunakan $A V$ shunt sebagai akses vaskular. Hasil ini sesuai dengan penelitian oleh Bawazier LA, yang menyatakan bahwa proporsi penderita CKD stadium 5 yang menjalani hemodialisis di RSUP Cipto Mangunkusumo Jakarta berdasarkan akses vaskular yang digunakan lebih tinggi $A V$ shunt sebesar $57,9 \% .{ }^{17}$ Penelitian oleh Ethayakumar (2018), juga menyatakan bahwa proporsi penderita CKD stadium 5 yang menjalani hemodialisis di sebuah rumah sakit negara Srilanka berdasarkan akses vaskular yang digunakan dengan semuanya menggunakan $A V$ shunt sebesar $100 \%$ dan tidak ada menggunakan metode akses vena femoral maupun dengan double lument. ${ }^{21}$ $A V$ shunt lebih sering digunakan pada penderita CKD stadium 5 yang menjalani hemodialisis. Hal ini kemungkinan disebabkan oleh beberapa hal. Menurut Mehrotra (2017), AV shunt merupakan metode akses vaskular yang berasosiasi dengan risiko komplikasi hemodialisis yang rendah serta pengurangan costs yang besar pada penderita CKD stadium 5 yang menjalani hemodialisis. ${ }^{22}$

Sebagian besar penderita CKD stadium 5 di RSUD Klungkung memiliki hasil pemeriksaan HbsAg negatif. Hal ini sesuai dengan penelitian oleh Bawazier LA, yang menyatakan bahwa proporsi penderita CKD stadium 5 yang menjalani hemodialisis di RSUP Cipto Mangunkusumo Jakarta berdasarkan status serologis HbsAg lebih tinggi dengan HbsAg negatif sebesar 53,8\%. ${ }^{17}$ Penelitian Guimaraes MNC et al, juga menyatakan bahwa proporsi penderita yang menjalani hemodialisis di sebuah rumah sakit negara Brazil berdasarkan status serologis HbsAg dengan semua HbsAg negatif sebesar $100 \%$ dan tidak ada dengan HbsAg positif. ${ }^{23}$ 
Proporsi penderita CKD stadium 5 di RSUD Klungkung berdasarkan status kadar hemoglobin $\mathrm{Hb})$ secara keseluruhan lebih tinggi dengan $\mathrm{Hb}$ $>10 \mathrm{gram} / \mathrm{dL}$. Hal ini tidak sesuai dengan penelitian Aisara S, yang menyatakan bahwa proporsi penderita CKD stadium 5 yang menjalani hemodialisis di RSUP Dr. M. Djamil Padang berdasarkan status kadar $\mathrm{Hb}$ lebih tinggi dengan $\mathrm{Hb}$ 7-10 gram/dL sebesar $68,3 \%{ }^{24}$ Penelitian oleh Alam $\mathrm{M}$ et al., juga menyatakan bahwa proporsi penderita CKD stadium 5 yang menjalani hemodialisis di sebuah rumah sakit negara Bangladesh berdasarkan status kadar Hb lebih tinggi dengan kadar $\mathrm{Hb} 7-11$ gram/dL sebesar $72 \%{ }^{19}$ Anemia merupakan salah satu komplikasi tersering dari CKD stadium 5 ataupun penyakit kronis lainnya seperti keganasan, sindrom metabolik, dan infeksi kronis apabila dilihat dari kadar $\mathrm{Hb}$ dalam pemeriksaan darah lengkap. ${ }^{25,26}$ Dalam penelitian ini, laki-laki lebih tinggi dengan kadar $\mathrm{Hb}>10$ gram/dL dibandingkan dengan perempuan yang lebih tinggi dengan kadar $\mathrm{Hb}$ diantara 7 - 10 gram/dL.

\section{SIMPULAN}

Pada penelitian ini, sebagian besar penderita CKD stadium 5 yang menjalani hemodialisis di RSUD Klungkung umur pertengahan, jenis kelamin lakilaki, tingkat pendidikan menengah, dominan sudah bekerja dan sudah menikah, dengan tahun pertama menjalani hemodialisis 1-5 tahun. Pada laki-laki, penyebab tersering CKD adalah pielonefritis kronis, sedangkan perempuan dengan hipertensi. Akses vaskular yang digunakan dominan dengan AV shunt, HbsAg negatif, serta dengan kadar $\mathrm{Hb}$ $>10 \mathrm{gram} / \mathrm{dL}$.

\section{KONFLIK KEPENTINGAN}

Tidak terdapat konflik kepentingan dalam penulisan laporan penelitian ini.

\section{ETIKA PENELITIAN}

Penelitian ini telah mematuhi prosedur Etika Penelitian yang tertulis sesuai dengan pedoman COPE ataupun ICMJE.

\section{PENDANAAN}

Tidak ada.

\section{KONTRIBUSI PENULIS}

Seluruh penulis berkontribusi terhadap penelitian ini baik dari penyusunan kerangka konsep, pengumpulan data, analisis data, hingga interpretasi data penelitian dalam bentuk publikasi.

\section{DAFTAR PUSTAKA}

1. Tjang YS, Pandelaki PAA. Factors Associated with Chronic Kidney Disease Among Patients Undergoing Hemodialysis. Journal of The Indonesias Medical Association. 2018;68(4):167-169.

2. Pranata S, Fauziah Y, Budisuari MA, Kusrini I. Riset Kesehatan Dasar dalam Angka Tahun 2013. Jakarta: Badan Penelitian dan Pengembangan Kesehatan Kemenkes RI; 2013.

3. Jha VK, Shashibhushan. Clinical Profile of Chronic Kidney Disease Patients in a Tertiary Care Hospital-An Observational Study. J Nephrol Kidney Dis. 2018;2(2):1016.

4. Chaudhari ST, Sadavarte AV, Chafekar D. Clinical Profile of End Stage Renal Disease in Patients Undergoing Hemodialysis. MVP Journal of Medical Sciences. 2017; 4(1):8-13.

5. Hecking M, Bieber BA, Ethier J, Kautzky-Willer A, Sunder-Plassmann G, Saemann MD, et al. Sex-specific differences in hemodialysis prevalence and practices and the male-to-female mortality rate: the Dialysis Outcomes and Practice Patterns Study (DOPPS). PLoS Med. 2014;11(10):e1001750.

6. Hill NR, Fatoba ST, Oke JL, et al. Global Prevalence of Chronic Kidney Disease-A Systematic Review and MetaAnalysis. PLoS One. 2016;11(7):e0158765.

7. Stanifer JW, Muiru A, Jafar TH, Patel UD. Chronic kidney disease in low- and middle-income countries. Nephrol Dial Transplant. 2016;31(6):868-874.

8. Kementerian Kesehatan Republik Indonesia (Kemenkes RI). Hasil Utama Riskesdas 2018. Badan Penelitian dan Pengembangan Kesehatan; 2018. [Tersedia pada: http:// www.depkes.go.id/resouces/download/info-terkini/ hasil-riskesdas-2018.pdf] [Akses: 10 Agustus 2019].

9. Prasad N, Jha V. Hemodialysis in Asia. Kidney Dis (Basel). 2015;1(3):165-177.

10. Kwong VW, Li PK. Peritoneal Dialysis in Asia. Kidney Dis (Basel). 2015;1(3):147-156.

11. Prodjosudjadi W, Suhardjono A. End-stage renal disease in Indonesia: treatment development. Ethn Dis. 2009;19(1 Suppl 1):S1-36.

12. Silbiger $\mathrm{S}$, Neugarten J. Gender and human chronic renal disease. Gend Med. 2008;5 Suppl A:S3-S10.

13. Nomani AZ, Iqbal M, Bacha F, Mughal S, Rajput HM, Badshah M, et al. Demographic Profile and Associations of Dialysis Dependent Chronic Kidney Disease Patients in Federal Capital of Pakistan. Pakistan Journal of Neurological Sciences. 2015;11(1):13-8.

14. de Oliveira HM Jr, Formiga FF, Alexandre Cda S. Clinical and epidemiological profile of chronic hemodialysis patients in João Pessoa--PB. J Bras Nefrol. 2014;36(3):367-374.

15. Dinas Kesehatan Pemerintah Provinsi Bali. Profil Kesehatan Provinsi Bali. 2017. [Tersedia pada: http://www. dikes.baliprov.go.id/download/profil-kesehatan-provinsibali-tahun-2017] [Diakses pada: 10 Agustus 2019].

16. Olim MF. Sociographic Profile of Hemodialysis Patients in Portugal. National Kidney Foundation Journal of Nephrology Social Work. 2018; 42(1):9-19.

17. Bawazier LA. Epidemiology Profile of Twice per Week Hemodialysis Patients of Top Referral National Hospital in Indonesia. eJKI. 2018;6(2):81-90.

18. Fogo AB, Lusco MA, Najafian B, Alpers CE. AJKD Atlas of Renal Pathology: Chronic Pyelonephritis. Am J Kidney Dis. 2016;68(4):e23-e25.

19. Alam M, Anissuzzaman A, Jahan N, Hossain MS. Clinical and Etiological Profile of Chronic Kidney Disease Patients on Hemodialysis in a Tertiary Care Hospital in Northern Part of Bangladesh. IOST Journal of Dental and Medical Sciences. 2018;17(8):42-5. 
20. Murphy D, McCulloch CE, Lin F, et al. Trends in Prevalence of Chronic Kidney Disease in the United States. Ann Intern Med. 2016;165(7):473-481.

21. Ethayakumar N, Umakanth M. Clinical Profile of End Stage Chronic Kidney Disease Undergoing HemodialysisStudy Conducted at Teaching Hospital Jaffna, Srilanka. Batticaloa Medical Journal. 2018;9:17-23.

22. Mehrotra R, Cheung AK, Meyer T, Nath KA. Vascular Access for Hemodialysis and Value-Based Purchasing for ESRD. J Am Soc Nephrol. 2017;28(2):395-397.

23. Guimarães MNC, Facincani T, Santos SSD. Hepatitis B status in hemodialysis patients. Arq Gastroenterol. 2017;54(4):356-358

24. Aisara S, Azmi S, Yanni M. Gambaran Klinis Penderita Penyakit Ginjal Kronik yang Menjalani Hemodialisis di RSUP Dr. M. Djamil Padang. Jurnal Kesehatan Andalas. 2018;7(1):42-50.
25. Prabawa IPY, Bhargah A, Liwang F, Tandio DA, Tandio AL, Lestari AAW, et al. Pretreatment Neutrophil-to-Lymphocyte ratio (NLR) and Platelet-to-Lymphocyte Ratio (PLR) as a Predictive Value of Hematological Markers in Cervical Cancer. Asian Pac J Cancer Prev. 2019;20(3):863-868.

26. Mulyani WRW, Sanjiwani MID, Sandra, Prabawa IPY, Lestari AAW, Wihandani DM, et al. Chaperone-Based Therapeutic Target Innovation: Heat Shock Protein 70 (HSP70) for Type 2 Diabetes Mellitus. Diabetes Metab Syndr Obes. 2020;13:559-568.

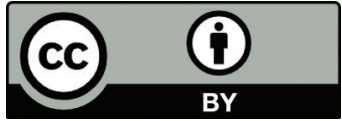

This work is licensed under a Creative Commons Attribution 